\title{
Selected combustion parameters of biogas at elevated pressure-temperature conditions
}

\begin{abstract}
Results from tests conducted in several RTD centers lead to conclusion that biogas as a potential fuel for the internal combustion (IC) spark ignited (SI) engine features with its satisfactory combustion predisposition causing smooth engine run without accidental misfiring or knock events. This good predisposition is obtained due to carbon dioxide $\left(\mathrm{CO}_{2}\right)$ content in the biogas. On the other hand, carbon dioxide as incombustible gas contribute to decrease in the brake power of the biogas fueled engine. To analyze mutual $\mathrm{CO}_{2}$ and $\mathrm{CH}_{4}$ content on biogas burning the combustion parameters as follows: adiabatic combustion temperature, laminar flame speed and ignition delay of biogas with various methane content were determined and presented in the paper. Additionally, these parameters for pure methane were also included in order to make comparison between each other. As computed, ignition delay, which has is strongly correlated with knock resistance, can change several times with temperature increase, but does not change remarkably with increase in methane content. Adiabatic combustion temperature does not also ought to influence on engine performance or increase in engine cooling and exhaust losses due to its insignificant changes. The largest change was observed in laminar flame speed, that can influence on development of the first premixed combustion phase.
\end{abstract}

Key words: biogas, fuel composition, parameters of combustion process

\section{Wybrane parametry procesu spalania biogazu w warunkach podwyższonego ciśnienia i przy podwyższonej temperaturze}

\begin{abstract}
Wyniki badań przeprowadzonych w różnych centrach badawczych świadczq o tym, iż biogaz można traktować jako potencjalne paliwo do silników spalinowych o zapłonie iskrowym. Zastosowanie tego paliwa sprawia, że silnik pracuje płynnie bez wypadania zapłonów i spalania stukowego. Dobre predyspozycje biogazu jako paliwa spowodowane sq z jednej strony zawartościa dwutlenku węgla $\left(\mathrm{CO}_{2}\right)$. Z drugiej jednak strony dwutlenek węgla jako gaz niepalny przyczynia się do obniżenia mocy silnika zasilanego biogazem. W artykule przedstawiono analize wzajemnej zależności $\mathrm{CO}_{2} i \mathrm{CH}_{4}$ zawartych $w$ biogazie i ich wptyw na następujace parametry procesu spalania: temperature adiabatycznego spalania, szybkość rozprzestrzeniania się płomienia laminarnego oraz opóźnienie zapłonu dla biogazu o zmiennej zawartości metanu. Parametry te porównano z parametrami procesu spalania dla czystego metanu. Zgodnie z obliczeniem, opóźnienie zapłonu, które jest ściśle zwiąane z odpornościa na spalanie stukowe, może się zmieniać znaczaco wraz ze wzrostem temperatury, ale nie zmienia się w istotny sposób wraz ze wzrostem zawartości metanu. Niewielkie zmiany temperatury adiabatycznego spalania nie powinny również wpływać na parametry pracy silnika oraz na wzrost strat chłodzenia lub strat wylotu. Największe zmiany zaobserwowano w szybkości rozprzestrzeniania się płomienia laminarnego, co może mieć wplyw na rozwój kinetycznej fazy spalania.
\end{abstract}

Słowa kluczowe: biogaz, skład paliwa, parametry procesu spalania

\section{Introduction}

In 2009 in the EU, biogas production was estimated to 8.3 million tonnes of oil equivalent (Mtoe) [1]. Furthermore, the theoretic potential of primary production from biogas in 2020 is estimated as 166 Mtoe [2]. Thus, biogas production and its energetic utilization can be managed as significant all over other energy sources. Nowadays, biogas is generally converted to electric power in power plants, CHP sets and Organic Rankine Cycle (ORC) based systems [10]. By forcing biogas utilization as fuel for traction engines it causes challenges to develop new technologies in this field, eg. airbiogas control systems. Thus, it requires detailed knowledge on biogas physical and chemical properties with particular focus on air-biogas mixture formation and its combustion. Apart from biogas parameters, such as the LHV, stoichiomet-

\section{Wprowadzenie}

W Unii Europejskiej w roku 2009 szacowana produkcja biogazu była na poziomie 8,3 miliona ton przeliczeniowego oleju napędowego (Mtoe) [1]. Teoretyczny potencjał produkcji biogazu w roku 2020 jest szacowany na 166 Mtoe [2]. Tak więc produkcję biogazu i jego energetyczne wykorzystanie można traktować jako znaczące pośród innych źródeł energii. Obecnie biogaz jest przede wszystkim poddawany konwersji na energię elektryczną w agregatach prądotwórczych, dużych zespołach CHP oraz w systemach z obiegiem Rankine'a (ORC - Organic Rankine Cycle).

Wykorzystanie biogazu jako paliwa do silników trakcyjnych wymusza rozwój nowych technologii w tej dziedzinie, np. odnośnie do systemów kontroli mieszaniny powietrza $\mathrm{z}$ biogazem. Problem ten wymaga szczegółowej wiedzy na 
ric air-to-fuel ratio $\left(\mathrm{A} / \mathrm{F}_{\text {stoic }}\right)$, Sonic Bievo index and Methane Number $(\mathrm{MN})$ there are additional parameters as: adiabatic combustion temperature, laminar flame speed and ignition delay, which should be determined and their impact on combustion should be analyzed as far as research activities in this field are concentrated on improving biogas combustion, increase in engine performance and eliminating knock. Due to relatively high incombustible content in biogas, engine power loss is observed. Hence, increase in compression ratio and boosting the engine are the main measures to overcome this drawback. In experiments using simulated biogas by Crookes $[3,4,7]$, compression ratios ranging from 11:1 to 13:1 were found to be suitable for operation without knock. In the case of a biogas fuelled engine, the compression ratios that can be employed can be considerably higher than normal as the $\mathrm{CO}_{2}$ present helps to suppress knock [5]. However, high compression ratios were found to increase $\mathrm{HC}$ and $\mathrm{NO}$ levels, but dilution by $\mathrm{N}_{2}$ and $\mathrm{CO}_{2}$ was found to be beneficial in lowering $\mathrm{NO}_{x}$. Nagalingam et al. [6] found that hydrogen addition extended the lean limit of combustion of natural gas due to its inherent nature, but it decreased the power due to an overall lower volumetric heating value. The $\mathrm{N}_{2}$ dilution test results show that an increase of inert gas in biogas was beneficial to thermal efficiency enhancement and $\mathrm{NO}_{x}$ emission reduction, while exacerbating THC emissions and cyclic variations. Then, as a way to achieve stable combustion for the lowest quality biogas, hydrogen enrichment was found as promising measure [12].

One of the efforts to overcome these drawbacks is a rise of compression ratio in a biogas engine. It enables improvement in engine performance, especially in thermal efficiency and power output. However, by increasing compression ratio, it can also exacerbate knock tendency and produce more nitrogen oxides $\left(\mathrm{NO}_{\mathrm{x}}\right)$ and hydrocarbon $(\mathrm{HC})$ emissions $[4,7]$.

Although, modeling and experimental work on the biogas engine is rich in results $[13-28,33]$, but there is relatively low number of papers taking attempts for finding correlation between fuel parameters and that fuel combustion progress with particular interest on combustion knock occurrence [29-32].

\section{Methodology}

Calculation of the parameters as follows: adiabatic combustion temperature (Ta), laminar flame speed (LFS) and ignition delay (ID) was proceeded with aid of Chemkin 4 and the GRI-Mech 3.0 (2000) mechanism for combustion kinetics. The adiabatic combustion temperature was determined at constant-volume conditions. It was calculated at assumption that dissociation of several species as eg. $\mathrm{H}_{2} \mathrm{O}$, $\mathrm{CO}_{2}$ takes place. Additionally, $\mathrm{OH}$ and $\mathrm{H}$ radicals and final products $\mathrm{NO}, \mathrm{CO}, \mathrm{CO}_{2}, \mathrm{H}_{2}$ were also determined at this equilibrium adiabatic temperature.

In literature there are several reaction mechanisms for modeling methane combustion at various environment conditions. Among others, the following reaction mechanisms for biogas combustion simulation can be distinguished: Smooke (1991), Konnov (2000), Leeds (2001), SKG03 (2004), GDF- temat właściwości fizyko-chemicznych biogazu, ze szczególnym uwzględnieniem procesu tworzenia mieszanek biogazu z powietrzem i ich spalania. Oprócz parametrów biogazu: wartości opałowej (LHV), stechiometrycznego zapotrzebowania powietrza $\left(\mathrm{A} / \mathrm{F}_{\text {stech }}\right)$, wskaźnika Sonic-Bievo oraz liczby metanowej, występują takie parametry, jak: temperatura adiabatycznego spalania, szybkość rozprzestrzeniania się płomienia laminarnego oraz opóźnienie zapłonu, które powinny być określone i których wpływ na proces spalania powinien być analizowany w kontekście poprawy procesu spalania biogazu, wzrostu osiągów silnika oraz wyeliminowania spalania stukowego.

Ze względu na stosunkowo dużą zawartość składników niepalnych w biogazie obserwuje się zmniejszenie mocy silników zasilanych tym paliwem. Zwiększenie stopnia sprężania oraz doładowanie silnika to główne działania zmierzające do wyeliminowania tej wady. Badania eksperymentalne $\mathrm{z}$ zastosowaniem biogazu, przeprowadzone przez Crookesa [3, 4, 7], wykazały, iż stopień sprężania z zakresu od 11:1 do 13:1 może być stosowany bez obaw wystąpienia spalania stukowego. W sytuacji zasilania silnika biogazem zastosowane stopnie sprężania mogą być wyższe niż normalne ze względu na obecność w biogazie dwutlenku węgla, który obniża skłonności do spalania stukowego [5]. Jednak duży stopień sprężania powoduje z jednej strony przyrost zawartości $\mathrm{HC}_{\mathrm{i}} \mathrm{NO}_{\mathrm{x}}$ w spalinach, z drugiej strony - efekt rozcieńczenia $\mathrm{N}_{2}$ oraz $\mathrm{CO}_{2}$ wpływa na obniżenie zawartości $\mathrm{NO}_{\mathrm{x}}$.

Nagalingam i in. [6] stwierdzili, że dodatek wodoru powoduje rozszerzenie granic spalania mieszanek ubogich gazu ziemnego, ale powoduje to jednoczesny spadek mocy, co wynika z małej objętościowej wartości opałowej wodoru. $\mathrm{Z}$ kolei wyniki badań związanych z rozcieńczaniem $\mathrm{N}_{2} \mathrm{w}$ biogazie pokazują, iż wzrost zawartości gazów obojętnych wpływa korzystnie na sprawność silnika i redukcję emisji $\mathrm{NO}_{\mathrm{x}}$, ale zwiększa emisję THC oraz zwiększa niepowtarzalność obiegu. Stwierdzono, iż wzbogacenie w wodór biogazu złej jakości wpływa korzystnie na poprawę stabilności pracy silnika [12].

Jednym z działań przezwyciężających te wady jest zwiększenie stopnia sprężania w silnikach zasilanych biogazem. Uzyskuje się wówczas wzrost osiągów silnika, w szczególności wzrost sprawności cieplnej i mocy. Jednakże przez zwiększenie stopnia sprężania narasta prawdopodobieństwo występowania spalania stukowego, rośnie emisja tlenków azotu $\left(\mathrm{NO}_{\mathrm{x}}\right)$ oraz węglowodorów $(\mathrm{HC})[4,7]$.

Mimo iż prace eksperymentalne i modelowanie związane z silnikami zasilanymi biogazem są bardzo bogate w wyniki [13 - 28, 33], to jednak mało jest artykułów poświęconych korelacji pomiędzy parametrami paliwa a samym procesem jego spalania, ze szczególnym uwzględnieniem występowania spalania stukowego [29 - 32].

\section{Metodologia}

Obliczenia temperatury adiabatycznego spalania $(\mathrm{Ta})$, szybkości rozprzestrzeniania się płomienia laminarnego (LFS) oraz opóźnienia zapłonu (ID) były prowadzone przy użyciu programu Chemkin 4 i przy wykorzystaniu mecha- 
kin (2004), Dagaut (2005), San Diego (2005). The GRIMech 3.0 [8] is designed to model methane and natural gas combustion, including NO formation and reburn chemistry. This mechanism contains 325 reactions and 53 species. The GRI-Mech mechanism was optimized for combustion of the mentioned fuels in the temperature range $1000-2500 \mathrm{~K}$, in the pressure range up to $10 \mathrm{bar}$, and at equivalence ratios from 0.1 to 5 for premixed systems. Although, the GRI-Mech 3.0 mechanism was found as optimized to maximal pressure of $10 \mathrm{~atm}$, but Chen et al. [9] concluded that this mechanism provides satisfactory results at pressure up to $30 \mathrm{~atm}$.

Biogas input to computing was modeled as a mixture of methane and carbon dioxide at various proportion expressed by methane volumetric content starting from 45 up to $70 \%$. The modeled combustion was carried out in the constantvolume reactor at pressure and temperature corresponding to normal state of 1 bar and $298.15 \mathrm{~K}$ and at elevated values of 27 bar and $675 \mathrm{~K}$, respectively. These elevated values were taken into account because they come from the end of compression stroke in a naturally aspirated engine with compression ratio of 12 .

\section{Results and discussion}

As known, the second major component of biogas is carbon dioxide. In this context, this gas can be considered as the inert one, hence it decreases lower heating value (LHV) (Fig. 1a) of the biogas due to reducing amounts of methane and air delivered to the engine cylinder. As result less specific air expressed by the $\mathrm{A} / \mathrm{F}_{\text {stoic }}$ is required for biogas stoichiometric combustion (Fig. 1b). Thus, finally, loss in engine power is expected due to decrease in the heating value of the air-biogas stoichiometric mixture $\left(\mathrm{LHV}_{\text {mix }}\right)$ (Fig. 1c).

a)
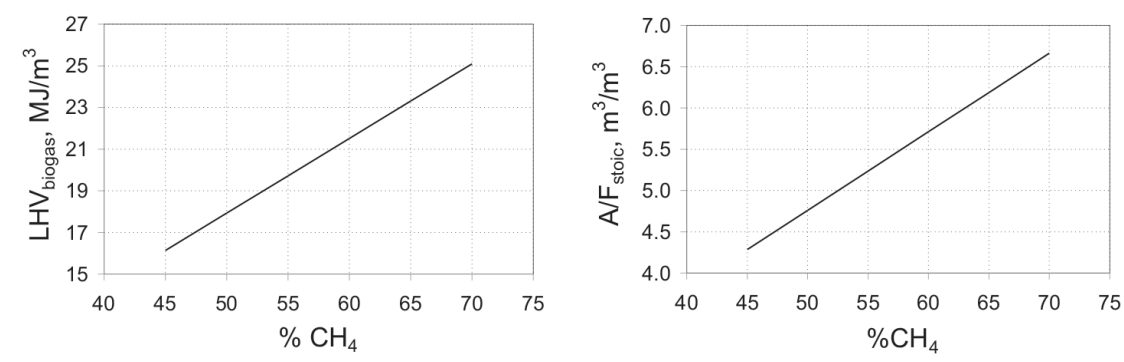

nizmu kinetyki spalania GRI-Mech 3.0 (2000). Temperaturę adiabatycznego spalania określono w warunkach stałej objętości. Obliczono ją przy uwzględnieniu występowania produktów dysocjacji niektórych związków, m.in. $\mathrm{H}_{2} \mathrm{O}$, $\mathrm{CO}_{2}$. Dodatkowo rodniki $\mathrm{OH}$ i $\mathrm{H}$ oraz produkty końcowe $\mathrm{NO}, \mathrm{CO}, \mathrm{CO}_{2}, \mathrm{H}_{2}$ zostały również obliczane dla temperatury adiabatycznego spalania.

W literaturze istnieje kilka mechanizmów służących do modelowania procesu spalania metanu w różnych warunkach otoczenia. Między innymi można wyróżnić następujące mechanizmy reakcji spalania biogazu: Smooke (1991), Konnov (2000), Leeds (2001), SKG03 (2004), GDF-kin, (2004), Dagaut (2005), San Diego (2005). Mechanizm GRI-Mech 3.0 [8] jest przeznaczony do modelowania procesu spalania metanu oraz gazu ziemnego. Zawiera on m.in. mechanizmy tworzenia NO. Mechanizm GRI-Mech to 325 reakcji elementarnych uwzględniających tworzenie 53 związków chemicznych. Został on zoptymalizowany do spalania powyższych paliw w zakresie temperatury od 1000 do $2500 \mathrm{~K}$ przy ciśnieniu do 10 bar i ekwiwalentnym współczynniku paliwa do powietrza $(E R=1 / \lambda)$ od 0,1 do 5. Mimo że mechanizm ten został zoptymalizowany do ciśnienia maksymalnego $10 \mathrm{~atm}$, to Chen $\mathrm{i}$ in. [9] stwierdzili, iż daje on zadowalające wyniki również przy ciśnieniu maksymalnym do $30 \mathrm{~atm}$.

$\mathrm{W}$ obliczeniach wykonanych $\mathrm{w}$ ramach tej pracy biogaz był symulowany jako mieszanina metanu i dwutlenku węgla w różnych proporcjach wyrażonych przez objętościową zawartość metanu, począwszy od 45 aż do $70 \%$. Modelowanie procesu spalania prowadzono w reaktorze o stałej objętości odpowiednio przy ciśnieniu i temperaturze dla warunków normalnych 1 bar i 298,15 K oraz przy wartościach podwyż-

Fig. 1. LHV of biogas (a), A/F $\mathrm{F}_{\text {stoic }}$ of biogas (b), LHV of biogas-air stoichiometric mixture (c) vs methane content Rys. 1. LHV biogazu (a), A/F $F_{\text {stech }}$ biogazu (b), LHV mieszanki stechiometrycznej biogazu z powietrzem (c) w funkcji zawartości metanu

As mentioned, the $\mathrm{CO}_{2}$ content is considered as inert gas with respect to engine performance, but it positively influences on knock resistance of biogas. As the knock indicator the methane number $(\mathrm{MN})$ is introduced for gaseous fuels. The $\mathrm{MN}$ goes up with higher $\mathrm{CO}_{2}$ content as depicted in the Fig. 2.

As presented in the Fig. 2 methane number for biogas is higher than that one for pure methane, due to dilution effect and heat accumulation by $\mathrm{CO}_{2}$ and its dissociation into $\mathrm{CO}$ at high flame temperature, that additionally reduces overall in-cylinder gas temperature. However, it should be noticed szonych do 27 bar i $675 \mathrm{~K}$. Zwiększone wartości uwzględniają koniec suwu sprężania silnika wolnossącego o stopniu sprężania równym 12 .

\section{Wyniki i dyskusja}

Jak wiadomo, jednym z dwóch głównych składników biogazu jest dwutlenek węgla. $\mathrm{Z}$ tego powodu $\mathrm{CO}_{2}$ jako gaz obojętny zmniejsza wartość opałową biogazu (LHV) ze względu na zmniejszenie ilości metanu dostarczanego do cylindra silnika (rys. 1a). W rezultacie do spalania stechiometrycznego biogazu wymagana jest mniejsza wartość 


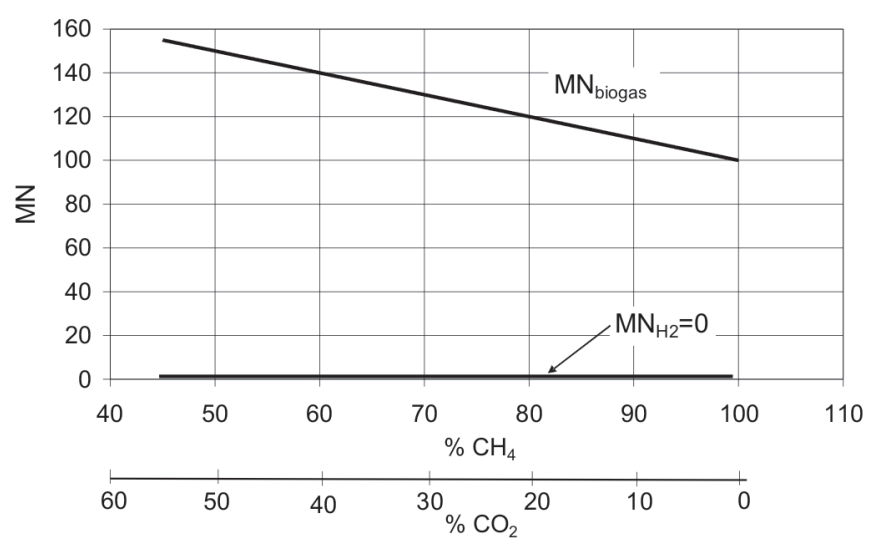

Fig. 2. Methane Number (MN) of biogas vs methane (optionally $\mathrm{CO}_{2}$ ) content Rys. 2. Liczba metanowa (MN) biogazu w funkcji zawartości metanu (ewentualnie $\mathrm{CO}_{2}$ )

that the $\mathrm{H}_{2} \mathrm{~S}$ content of $1 \%$, which usually appears in raw biogas, can remarkably deteriorate biogas knock resistance and reduce the $\mathrm{MN}$ to value below $100[10,15]$.

Correlation between adiabatic temperature Ta and methane percentage content in biogas is presented in the Fig. 3. The Ta is determined as temperature of equilibrium state including products of dissociation and several intermediate species occurring at this high temperature. Temperature Ta is computed with reactor's initial pressure-temperature of 1 bar and $298 \mathrm{~K}$, and 27 bar and $675 \mathrm{~K}$, respectively. As plotted, it rises with methane content increase mostly due to higher amounts of heat released during biogas combustion.

At the same working conditions as it was for the Ta, laminar flame speed (LFS) was determined. As shown in the Fig. 4, it increases with increase of methane content. Additionally, one can observe increase in the LFS with increasing the initial temperature. The laminar flame speed is a parameter, which can be used as an indicator for evaluating combustion rate and flame kernel development of biogas at its first combustion phase just pass its ignition in the SI engine. In the Fig.

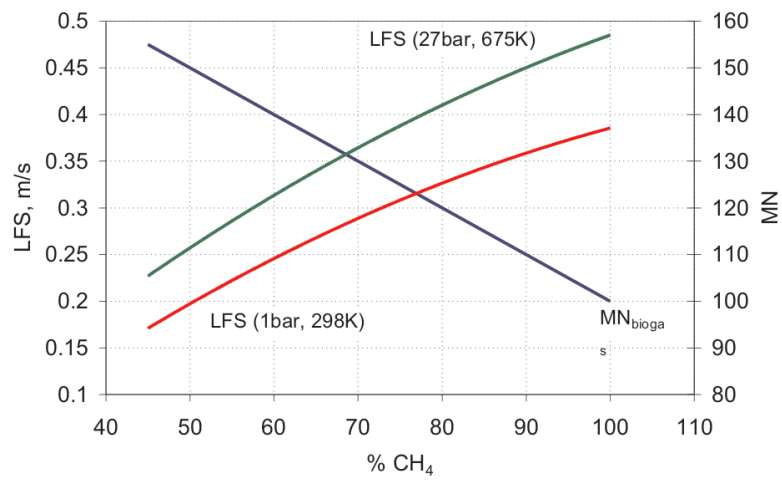

Fig. 4. Laminar flame speed (LFS) and Methane Number (MN) of biogas vs methane content at two different initial p-T conditions

Rys. 4. Szybkość rozprzestrzeniania się płomienia laminarnego (LFS) i liczba metanowa biogazu (MN) w funkcji zawartości metanu dla dwóch różnych warunków początkowych p-T stechiometrycznego zapotrzebowania powietrza $\mathrm{A} / \mathrm{F}_{\text {stech }}$ (rys. 1b). Podsumowując, zmniejszenie wartości opałowej stechiometrycznej mieszanki powietrza z biogazem $\left(\mathrm{LHV}_{\text {mix }}\right)$ powoduje utratę mocy silnika (rys. 1c).

Jak wspomniano na wstępie, $\mathrm{CO}_{2}$ jest gazem obojętnym, który nie wpływa na osiągi silnika, ale pozytywnie wpływa na odporność biogazu na spalanie stukowe. Dla paliw gazowych miarą odporności na spalanie stukowe jest liczba metanowa. Ze wzrostem zawartości $\mathrm{CO}_{2}$ rośnie MN gazu - rys. 2.

Jak przedstawiono na rys. 2, liczba metanowa (MN) biogazu jest większa w porównaniu do czystego metanu, ze względu na efekt rozcieńczenia i akumulacji ciepła przez $\mathrm{CO}_{2}$ w biogazie oraz dysocjacji $\mathrm{CO}_{2}$ na $\mathrm{CO}$ w wysokiej temperaturze płomienia, co dodatkowo obniża temperaturę gazu w cylindrze. Należy jednak zauważyć, że obniżenie MN biogazu poniżej wartości 100, a tym samym pogorszenie odporności biogazu na spalanie stukowe, może być wywołane przez zawartość $\mathrm{H}_{2} \mathrm{~S}$ w ilości $1 \%$, który zazwyczaj występuje w świeżo wytworzonym

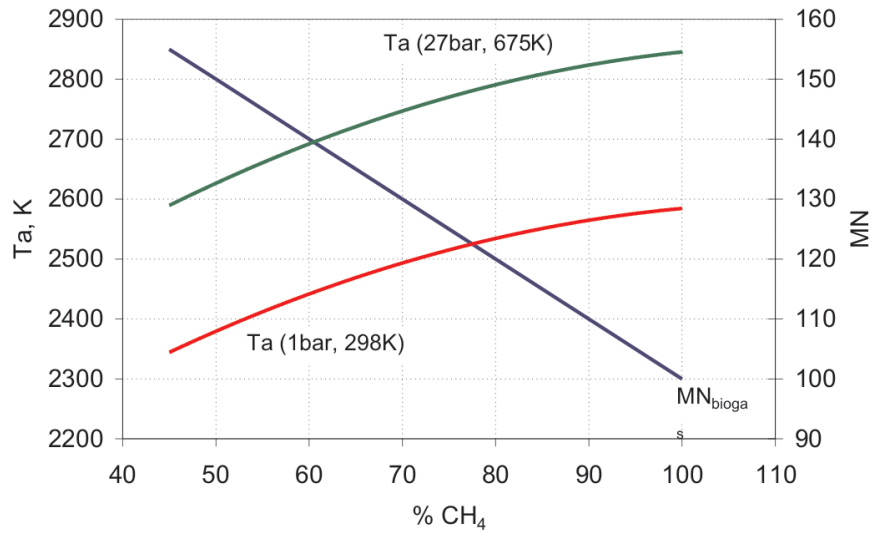

Fig. 3. Adiabatic temperature Ta and Methane Number (MN) of biogas vs methane content at two different initial p-T conditions

Rys. 3. Temperatura adiabatycznego spalania (Ta) i liczba metanowa (MN) biogazu w funkcji zawartości metanu dla dwóch różnych warunków początkowych $p-T$

biogazie [10, 15]. Związek pomiędzy temperaturą adiabatycznego spalania Ta i procentową zawartością metanu w biogazie przedstawiono na rys. 3. Temperatura Ta określa temperaturę stanu równowagi, z produktami dysocjacji i kilkoma pośrednimi składnikami reakcji występującymi w tej wysokiej temperaturze. Temperatura Ta jest obliczana w reaktorze dla dwóch początkowych wartości ciśnienia i temperatury, 1 bar i $298 \mathrm{~K}$ oraz 27 bar i $675 \mathrm{~K}$. Na wykresie Ta rośnie ze wzrostem zawartości metanu głównie ze względu na większą ilość wydzielonego ciepła podczas spalania biogazu.

Dla warunków pracy odpowiadających temperaturze Ta określono szybkość rozprzestrzeniania się płomienia laminarnego (LFS). Jak przedstawiono na rys. 4, wzrost LFS wynika ze wzrostu zawartości metanu w biogazie. Dodatkowo można zaobserwować wzrost LFS wraz ze wzrostem 
4 background, there is an additional plot of the biogas MN vs $\mathrm{CH}_{4}$ percentage in biogas. As depicted, there is negative correlation between the LFS and the MN, however, it is difficult to confirm such the correlation might exist. If some assumes, that the higher LFS contributes to higher combustion pressure pulsations resulted from accelerating combustion process, then explanation for negative correlation between the LFS and the MN of biogas makes sense.

Next parameter of the interest is ignition delay (ID). This parameter is defined as such a period of time, during which combustion has been developing from its initiation up to obtaining maximum in heat release rate in a closed constant-volume reactor where both fuel and oxidizer are premixed and they are at temperature higher than the fuel self-ignition temperature. The results for biogas ignition delay at temperature of 900,1000 and $1100 \mathrm{~K}$ are presented in the Figures $5 \mathrm{a}, \mathrm{b}$ and $\mathrm{c}$, respectively.

a)

b)
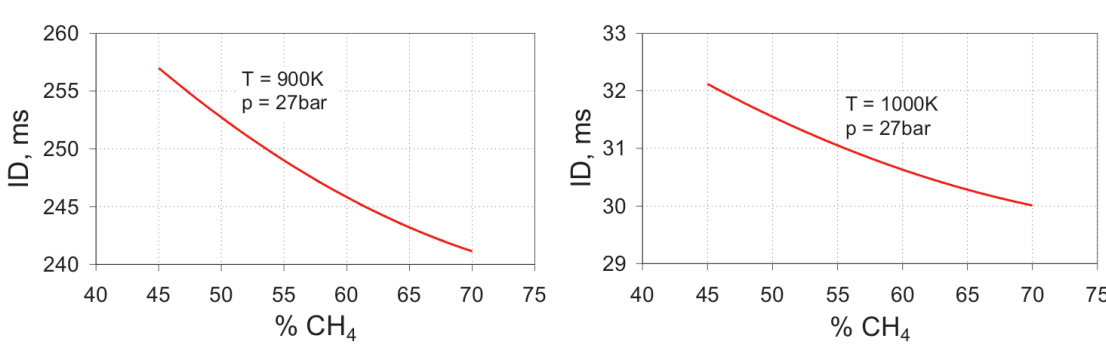

temperatury początkowej. Szybkość rozprzestrzeniania się płomienia laminarnego jest parametrem, który w silniku ZI może być wykorzystywany jako wskaźnik do oceny szybkość spalania i rozwoju jądra płomienia biogazu w pierwszej fazie spalania od chwili zapłonu. Podstawę wykresów na rys. 4 stanowi zależność pomiędzy MN biogazu a procentową zawartością $\mathrm{CH}_{4}$ w biogazie. Jak wynika $\mathrm{z}$ analizy wykresów, stwierdzono ujemną korelację pomiędzy LFS i MN, jednak trudno jest w praktyczny sposób potwierdzić istnienie takiego związku. Jeśli założy się, że wyższa LFS powoduje wzrost pulsacji ciśnienia spalania, a w rezultacie przyspieszenie procesu spalania, to wówczas taka ujemna korelacja pomiędzy LFS i MN biogazu nabiera logicznego sensu.

Kolejnym, analizowanym parametrem jest opóźnienie zapłonu (ID). Parametr ten jest zdefiniowany jako czas, w którym spalanie rozwija się od jego inicjacji do uzyskania maksymalnej szybkości wydzielania ciepła w zamkniętej,

Fig. 5. Ignition delay (ID) and Methane Number (MN) of biogas vs methane content at three different initial temperature Rys. 5. Opóźnienie zapłonu (ID) i liczba metanowa biogazu (MN) w funkcji zawartości metanu dla trzech różnych wartości temperatury początkowej

As plotted, the ID lengthens with decreasing the $\mathrm{CH}_{4}$ content, that is identically equaled to the $\mathrm{CO}_{2}$ content increase if one assumes the $\mathrm{CO}_{2}$ content comes from subtracting $\mathrm{CH}_{4}$ content from $100 \%$. The $\mathrm{CO}_{2}$ addition slows down reaction rates during combustion initiation. However, this drop in the ID vs $\mathrm{CH}_{4}$ content in relative numbers cannot exceed $7 \%$ (Fig. 5c), thus, it can be seen as insignificant with respect to analyze its impact on potential knock occurrence. This remark is important, if anyone wants to find clear correlation between biogas knock resistance by the $\mathrm{MN}_{\text {biogas }}$ and methane content in biogas. As presented in the Fig. $5 \mathrm{c}$, these both curves are inline with each other, but drop in the $\mathrm{MN}_{\text {biogas }}$ is much higher then drop in the ID computed at the same constant temperature. Therefore, one can conclude, the correlation between the MN and the ID is not directly caused by the $\mathrm{CH}_{4}$ content but by combined effect of the following: the LFS, the Ta and mostly by $\mathrm{H}$ and $\mathrm{OH}$ radicals, which concentrations in flames vary significantly with variable $\mathrm{CH}_{4}$ content (Fig. 6b, c).

Additionally, in the Fig. 6a nitric oxide (NO) and hydrogen diatomic $\left(\mathrm{H}_{2}\right)$ are plotted. Hydrogen $\mathrm{H}_{2}$ can be treated not only as product of water dissociation at flame temperature, but also as precursor for $\mathrm{H}$ radical, which together with the $\mathrm{OH}$ plays crucial role at the knock onset. As expected, the NO increases with the $\mathrm{CH}_{4}$ content increase due to higher flame temperature stałej objętości reaktora, gdzie zarówno paliwo, jak i utleniacz są wstępnie wymieszane $\mathrm{i}$ ich temperatura jest powyżej temperatury samozapłonu paliwa. Na rysunkach $5 \mathrm{a}, \mathrm{b}$ i c przedstawiono wyniki obliczeń wartości opóźnienia zapłonu biogazu w zależności od różnej zawartości metanu w tym biogazie dla 3 różnych wartości temperatury początkowej biogazu równej 900, $1000 \mathrm{i} 1100 \mathrm{~K}$.

Jak wynika z analizy rysunku, zmniejszenie udziału $\mathrm{CH}_{4}$ powoduje wydłużenie ID; podobna zależność występuje przy zwiększaniu udziału $\mathrm{CO}_{2}$ przy założeniu, że zawartość $\mathrm{CO}_{2}$ otrzymuje się przez odjęcie od $100 \%$ udziału $\mathrm{CH}_{4}$. Dodanie $\mathrm{CO}_{2}$ wpływa na zmniejszenie szybkości reakcji podczas inicjowania spalania. Jednakże względny spadek ID przy zmianie zawartości $\mathrm{CH}_{4}$ od 45 do $70 \%$ nie przekracza $7 \%$ (rys. 5c), zatem może być postrzegany jako nieistotny $\mathrm{w}$ odniesieniu do analizy jego wpływu na możliwość wystąpienia spalania stukowego. Ta uwaga jest ważna, jeśli chce się znaleźć wyraźną korelację pomiędzy odpornością biogazu na spalanie stukowe a liczbą metanową biogazu $\mathrm{MN}_{\text {biogas }}$ i zawartością metanu w biogazie. Jak przedstawiono na rysunku $5 \mathrm{c}$, obie krzywe pozostają ze sobą w tym samym trendzie, ale spadek $\mathrm{MN}_{\text {biogas }}$ jest znacznie większy niż spadek ID obliczony dla tej samej, stałej temperatury. Można także stwierdzić, że korelacja pomiędzy MN i ID nie jest bezpośrednio spowodowana przez zawartość $\mathrm{CH}_{4}$, 
a)

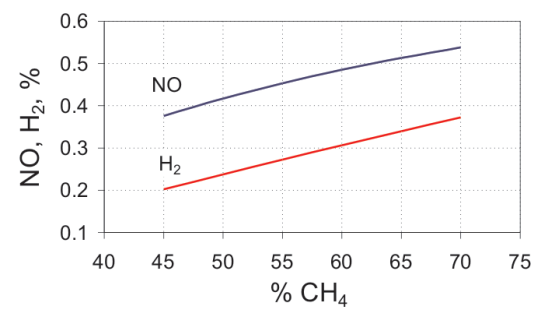

b)

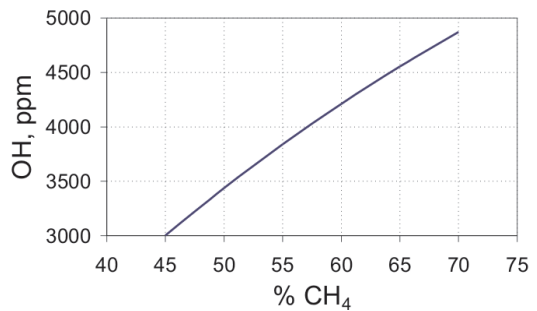

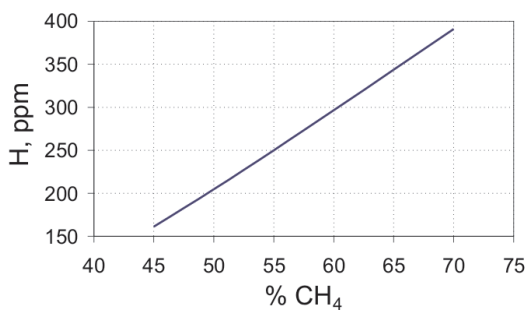

Fig. 6. $\mathrm{NO}$ and $\mathrm{H}_{2}$ content at temperature Ta (a), OH content at temperature Ta (b), $\mathrm{H}$ content at temperature Ta (c) vs methane content Rys. 6. Zawartość $\mathrm{NO}$ i $\mathrm{H}_{2}$ w temperaturze Ta (a), zawartość OH w temperaturze Ta (b), zawartość H w temperaturze Ta (c) w zależności od zawartości metanu

a)

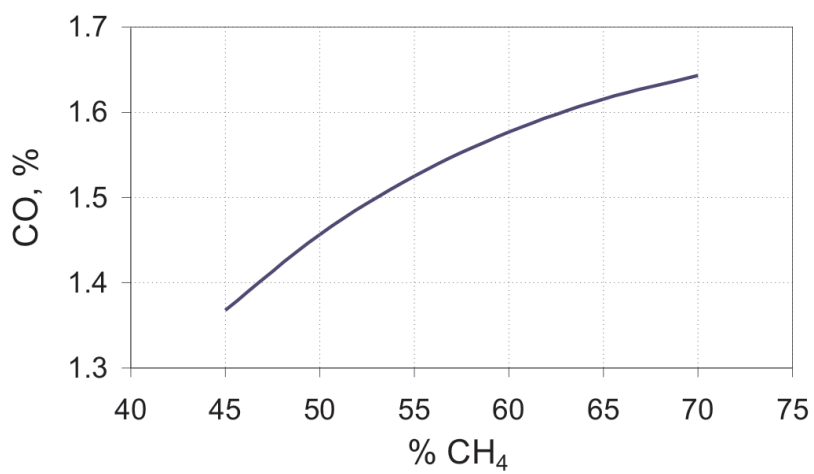

b)

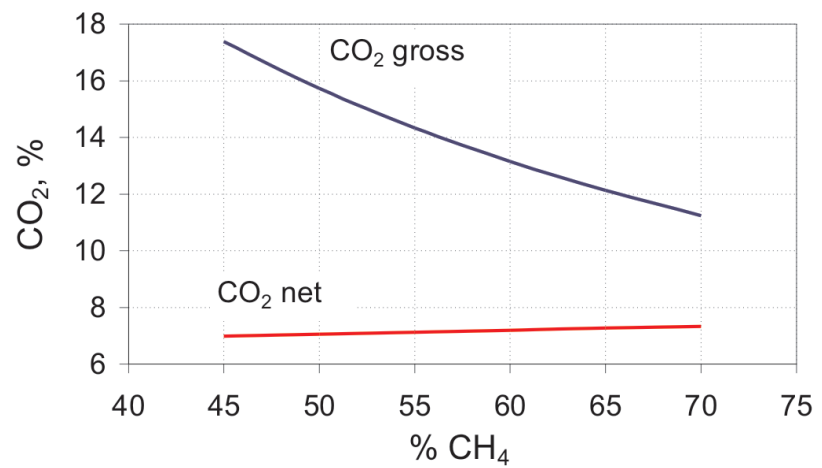

Fig. 7. CO content at temperature $\mathrm{Ta}(\mathrm{a}), \mathrm{CO}_{2}$ content at temperature $\mathrm{Ta}(\mathrm{b})$ vs methane content

Rys. 7. Zawartość CO przy temperaturze Ta (a), zawartość CO ${ }_{2}$ przy temperaturze Ta (b) w zależności od zawartości metanu

Ta. The same correlation, as observed for the NO, concerns $\mathrm{CO}$ concentration vs methane content (Fig. 7a). This phenomena can be explained by dissociation of $\mathrm{CO}_{2}$ at high flame temperature. Thus, $\mathrm{CO}_{2}$ dissociation contributes to reduction of the $\mathrm{CO}_{2}$ concentration in biogas flame zone as plotted in the Fig. 7b. However, concentration of $\mathrm{CO}_{2 \text {,gross }}$ is charged with $\mathrm{CO}_{2}$ concentration coming from reagent site. Therefore, $\mathrm{CO}_{2, \text { net }}$ which was defined as difference between $\mathrm{CO}_{2 \text {,gross }}$ and $\mathrm{CO}_{2}$ content in biogas, was plotted. As observed, the $\mathrm{CO}_{2 \text { net }}$ slightly increases with increase in the $\mathrm{CH}_{4}$ content.

\section{Conclusions}

Analysis presented in the paper concerns selected physical-chemical parameters of biogas referring to its premixed combustion in a spark ignition reciprocating engine. The properties taken into account are as follows: adiabatic combustion temperature (Ta), laminar flame speed (LFS) and ignition delay (ID). Correlation between these parameters and methane content in biogas was determined. Additionally, attempts to find clear trends between these parameters, methane number and lower heating value of biogas-air stoichiometric mixture $\left(\mathrm{LHV}_{\text {mix }}\right)$ were also taken. Here are the conclusions from the conducted analysis:

- With increase in methane content from $45 \%$ to $70 \%$ (that rises by $56 \%$ in reference to the $\mathrm{CH}_{4}=45 \%$ ) these quantities were changed as follows: ale przez połączony efekt takich parametrów, jak: LFS, Ta, a najbardziej przez rodniki $\mathrm{H}$ i OH, których stężenie w płomieniu może bardzo znacząco się zmieniać przy różnej zawartości $\mathrm{CH}_{4}$ (rys. 6b, c).

Dodatkowo na rys. 6a przedstawiono zawartość tlenku azotu (NO) i dwuatomowego wodoru $\left(\mathrm{H}_{2}\right)$. Wodór $\mathrm{H}_{2}$ może być traktowany nie tylko jako produkt dysocjacji wody w temperaturze płomienia, lecz także jako prekursor dla rodnika $\mathrm{H}$, który wraz z $\mathrm{OH}$ odgrywa kluczową rolę $\mathrm{w}$ powstawaniu stuku. Zgodnie z oczekiwaniami, zawartość NO wzrasta wraz ze wzrostem zawartości $\mathrm{CH}_{4}$ ze względu na wyższą temperatura płomienia Ta. Tę samą zależność jak dla NO można zaobserwować dla stężenia CO dla różnej zawartości metanu (rys. 7a). Zjawisko to można wyjaśnić jako dysocjację $\mathrm{CO}_{2} \mathrm{w}$ wysokiej temperaturze płomienia. Tak więc dysocjacja $\mathrm{CO}_{2}$ przyczynia się do zmniejszenia koncentracji $\mathrm{CO}_{2} \mathrm{w}$ strefie płomienia biogazu, co pokazano na rysunku 7b. Emisja $\mathrm{CO}_{2 \text {,gross }}$ jest zdefiniowana jako suma $\mathrm{CO}_{2}$ pochodzącego ze spalania metanu i $\mathrm{CO}_{2}$ będącego balastem biogazu. Stąd $\mathrm{CO}_{2 \text {,gross }}$ ulega zwiększaniu o zawartość $\mathrm{CO}_{2}$ pochodzącą ze strony reagentów wraz ze zmniejszaniem się zawartości $\mathrm{CH}_{4}$. $\mathrm{Na}$ rysunku $7 \mathrm{~b}$ dodatkowo przedstawiono stężenie $\mathrm{CO}_{2, \text { net }}$, które zostało zdefiniowane jako różnica między $\mathrm{CO}_{2 \text {,gross }}$ i zawartością $\mathrm{CO}_{2}$ w biogazie. Zauważono, że $\mathrm{CO}_{2 \text { net }}$ nieznacznie zwiększa się wraz ze wzrostem zawartości $\mathrm{CH}_{4}$, przy czym należy pamiętać, że $\mathrm{CO}_{2, \text { net }}$ nie pochodzi 
- adiabatic combustion temperature by $6.2 \%$ (from 2590 to $2750 \mathrm{~K}$ ),

- laminar flame speed by $60 \%$ (from 22.6 to $36.4 \mathrm{~cm}$ ),

- ignition delay by $6.5 \%$,

- $\mathrm{LHV}_{\text {mix }}$ by $6.7 \%$ (from 3.05 to $3.27 \mathrm{MJ} / \mathrm{nm}^{3}$ )

- and methane number by $16 \%$ (from 155 to 130 ).

- As found, only change in the LFS is of the similar order as the change in the $\mathrm{CH}_{4}$ content. The LFS can be in satisfactory correlation with global reaction rate of biogas combustion. As presented in the figure $7 \mathrm{~b}$ and $\mathrm{c}$ radicals $\mathrm{OH}$ and $\mathrm{H}$, which are very active, are also increased by the same order or even more with the $\mathrm{CH}_{4}$ content increase. From this point of view the LFS increases with increase in the $\mathrm{CH}_{4}$ content, so does overall combustion duration. Extended combustion might cause increase in exhaust thermal losses from the engine.

- With respect to engine performance, both the Ta and the $\mathrm{LHV}_{\text {mix }}$, which can affect on heat transfer to engine cooling system and to power loss respectively, are only slightly changed with increase in the $\mathrm{CH}_{4}$ content.

- The most strong parameter influencing on knock resistance of fuel is ignition delay. However, it also changes insignificantly with change in the $\mathrm{CH}_{4}$ content, but it rapidly shortens with increase in temperature of air-biogas premixed mixture. As presented in the figure 5, ignition delay gets shortened by $5-6$ times with temperature increase by $100 \mathrm{~K}$.

\section{Nomenclature/Oznaczenia}

$\mathrm{Ta}$ adiabatic combustion temperature/temperatura adiabatycznego spalania, $\mathrm{K},{ }^{\circ} \mathrm{C}$

LFS laminar flame speed/szybkość rozprzestrzeniania się ptomienia laminarnego, $\mathrm{m} / \mathrm{s}$

ID ignition delay/opóźnienie zapłonu, ms

LHV lower heating value/wartość opałowa, $\mathrm{MJ} / \mathrm{kg}, \mathrm{MJ} / \mathrm{nm}^{3}$

$\mathrm{A} / \mathrm{F}_{\text {stoic }}$ stoichiometric air-to-fuel ratio/stechiometryczne zapotrzebowanie powietrza

ER equivalence ratio/wspótczynnik paliwa do powietrza (odwrotność współczynnika nadmiaru powietrza)

MN methane number/liczba metanowa

Paper reviewed/Artykut recenzowany wyłącznie od zupełnego spalania metanu, ale dodatkowo uwzględnia reakcje dysocjacji pierwotnego $\mathrm{CO}_{2}$.

\section{Wnioski}

Przedstawiona w artykule analiza dotyczy wybranych parametrów fizykochemicznych biogazu w odniesieniu do spalania go w silniku o zapłonem iskrowym. W analizie tej uwzględniono następujące wielkości: adiabatyczną temperaturę spalania (Ta), prędkość płomienia laminarnego (LFS) i opóźnienie zapłonu (ID). Została również określona korelacja pomiędzy tymi parametrami i zawartością metanu w biogazie. Dodatkowo podjęto próbę znalezienia zależności pomiędzy tymi parametrami a liczbą metanową i wartością opałową $\left(\mathrm{LHV}_{\text {mix }}\right)$ stechiometrycznej mieszanki biogaz-powietrze. Wyciągnięto następujące wnioski z przeprowadzonej analizy:

- wraz ze wzrostem zawartości metanu z 45\% do 70\% (56\% wzrost w stosunku do $\mathrm{CH}_{4}=45 \%$ ) wartości te zmieniały się następująco:

- temperatura adiabatycznego spalania (Ta) o 6,2\% (z 2590 do $2750 \mathrm{~K}$ ),

- prędkość spalania laminarnego (LFS) o 60\% (z 22,6 do $36,4 \mathrm{~cm})$,

- opóźnienie zapłonu (ID) o 6,5\%,

- wartość opałowa mieszanki $\left(\mathrm{LHV}_{\text {mix }}\right.$ ) o 6,7\% (z 3,05 do $\left.3,27 \mathrm{MJ} / \mathrm{nm}^{3}\right)$,

- liczba metanowa (MN) o 16\% (z 155 do 130).

- Stwierdzono, że jedynie zmiany LFS są zbliżone do zmian zawartości $\mathrm{CH}_{4}$. Zatem LFS może być zadowalająco skorelowana z szybkością globalnej reakcji spalania biogazu. Jak przedstawiono na rysunku 6 b i c, zawartość rodników $\mathrm{OH}$ i H, które są bardzo aktywne, szybko wzrasta wraz ze wzrostem udziału $\mathrm{CH}_{4}$ w biogazie.

- W odniesieniu do osiągów silnika zarówno Ta, jak i $\mathrm{LHV}_{\text {mix }}$, które mogą mieć wpływ na straty ciepła do układu chłodzenia silnika i odpowiednio straty mocy, zmieniają się nieznacznie ze wzrostem zawartości $\mathrm{CH}_{4}$.

- Parametrem najsilniej wpływającym na odporność paliwa na spalanie stukowe jest opóźnienie zapłonu ID. Jednakże zmienia się ono nieznacznie ze zmianą zawartości $\mathrm{CH}_{4}$, natomiast ulega szybkiemu skróceniu ze wzrostem temperatury mieszaniny powietrze-biogaz. Jak przedstawiono na rysunku 5, opóźnienie zapłonu zmniejsza się 5-6-krotnie ze wzrostem temperatury o $100 \mathrm{~K}$.

\section{Bibliography/Literatura}

[1] http://www.eurobserv-er.org/pdf/baro200b.pdf

[2] http://www.aebiom.org/IMG/pdf/Brochure_BiogasRoadmap_WEB.pdf

[3] Huang J., Crookes R.: Assessment of simulated biogas as a fuel for the spark ignition engine. Fuel, 1998, 77(15), 793-801.

[4] Crookes R.J.: Comparative bio fuel performance in internal combustion engines. Int J Biomass Bioenergy, 2006, 30, 461-468.

[5] Jingdang H., Crookes R.J.: Assessment of simulated biogas as a fuel for the spark ignition engine. Fuel, 1998, 77(15), 793-1801.

[6] Nagalingam B., Duebel F., Schmillen K.: Performance study using natural gas, hydrogen supplemented natural gas and

hydrogen in AVL research engine. Int J Hydrogen Energy, 1983, 8(9), 715-720.

[7] Korakianitis T., Namasivayam A.M., Crookes R.J.: Naturalgas fueled spark ignition (SI) and compression-ignition (CI) engine performance and emissions. Prog Energy Combust Sci, 2011, 37, 89-112.

[8] Smith G.P., Golden D.M., Frenklach M., Moriarty N.W., Eiteneer B., Goldenberg M., Bowman C.T., Hanson R.H., Song S., Gardiner W.C., Lissianski V.V. and Zhiwei Qin Z., http:// www.me.berkeley.edu/gri_mech/.

[9] Mallampalli H.P., Fletcher T.H., Chen J.Y.: Evaluation of CH4/ NOx Global Mechanisms Used for Modeling Lean Premixed Turbulent Combustion of Natural Gas, Paper 96F-098, Pre- 
sented at the Fall Meeting of the Western States Section of the Combustion Institute, October 28-29, 1996.

[10] www.biogasmax.eu.

[11] Mitzlaff K.: Engines for biogas. Published by Friedr. Vieweg \& Sohn Verlagsgesellschaft GmbH, 1988.

[12] Park Ch., Park S., Lee Y., Kim Ch., Lee S., Moriyoshi Y.: Performance and emission characteristics of a SI engine fueled by low calorific biogas blended with hydrogen. International Journal of Hydrogen Energy, 2011, 36, 10080-10088.

[13] Porpatham E., Ramesh A., Nagalingam B.: Investigation on the effect of concentration of methane in biogas when used as a fuel for a spark ignition engine. Fuel, 2008, 87, 1651-1659.

[14] Porpatham E., Ramesh A., Nagalingam B.: Effect of hydrogen addition on the performance of a biogas fuelled spark ignition engine. International Journal of Hydrogen Energy, 2007, 32, 2057-2065.

[15] Herle J.V., Membrezb Y., Olivier Bucheli O.: Biogas as a fuel source for SOFC co-generators. Journal of Power Sources, 2004, 127, 300-312.

[16] Jamrozik A., Kociszewski A., Sosnowski M., Tutak W.: Simulation of combustion in SI engine with prechamber. CADMD'2006, CAD in Machinery Design Implementation and Educational Problems, Polyana, Ukraine, May 2006, 66-69.

[17] Jamrozik A., Tutak W., Kociszewski A., Sosnowski M.: Numerical Analysis of Influence of Prechamber Geometry in IC Engine with Two Stage Combustion System on Engine Work Cycle Parameters. Journal of KONES, Warsaw 2006, Vol 13, No 2, 133-142.

[18] Tutak W., Jamrozik A., Kociszewski A., Sosnowski M.: Numerical analysis of initial swirl profile influence on modeled piston engine work cycle parameters. Combustion Engines/ Silniki Spalinowe, 2007-SC2, 401-407.

[19] Kociszewski A., Jamrozik A., Sosnowski M., Tutak W.: Simulation of combustion in multi spark plug engine in KIVA-3V. Combustion Engines/Silniki Spalinowe. 2007-SC2, 212-219.

[20] Kociszewski A.: Numerical analysis of spark plugs number influence on selected parameters of combustion in piston engine. Combustion Engines/Silniki Spalinowe, No. 1/2008 (132), 50-55.

[21] Kociszewski A.: Three-dimensional modelling and experiment on combustion in multipoint spark ignition engine. Memstech 2009, Lviv-Polyana, Ukraine 2009, 20-23.

[22] Jamrozik A., Tutak W.: Modelling of combustion process in the gas test engine. Memstech 2010, Lviv - Polyana 2010, 14-17.

[23] Tutak W., Jamrozik A.: Numerical analysis of some parameters of gas engine. Commission of Motorization and Power Industry

Wojciech Tutak, DEng. - doctor in the Faculty of Mechanical Engineering and Computer Science of Częstochowa University of Technology.

Dr inż. Wojciech Tutak - adiunkt na Wydziale Inżynierii Mechanicznej i Informatyki Politechniki Częstochowskiej.

e-mail: tutak@imtits.pcz.czest.pl

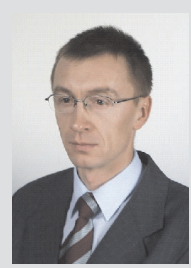

Stanisław Szwaja, DEng. - doctor in the Faculty of Mechanical Engineering and Computer Science at Częstochowa University of Technology.

Dr inż. Stanisław Szwaja - adiunkt na Wydziale Inżynierii Mechanicznej i Informatyki Politechniki Częstochowskiej.

e-mail:szwaja@imc.pcz.czest.pl in Agriculture Polish Academy of Science Branch in Lublin, Lublin 2010, Volume X, 491-502.

[24] Tutak W., Jamrozik A.: Modelling of the thermal cycle of gas engine using AVL Fire Software. Combustion Engines/Silniki Spalinowe, No. 2/2010 (141), 105-113.

[25] Sosnowski M., Tutak W., Jamrozik A., Kociszewski A.: Modeling of the thermal cycle piston internal combustion engine with spark ignition engines including exhaust gas recirculation. Edukacja Techniczna i Informatyczna V, Czestochowa 2010, 29-38.

[26] Tutak W., Jamrozik A., Kociszewski A.: Improved emission characteristics of SI test engine by EGR. Memstech 2011, Lviv - Polyana 2011, 101-103.

[27] Tutak W., Jamrozik A., Kociszewski A.: Three dimensional modelling of combustion process In SI engine with Exhaust Gas Recirculation. 10th Jubilee International Conference on Heat Engines and Environmental Protection, Hungary 2011, ref. 27, 203-208.

[28] Cupiał K., Tutak W., Jamrozik A., Kociszewski A.: The accuracy of modelling of the thermal cycle of a self-ignition engine. Combustion Engines/Silniki Spalinowe, No. 1/2011 (144), 37-48.

[29] Naber J.D., Szwaja S.: Statistical approach to characterize combustion knock in the hydrogen fuelled SI engine, Journal of Kones, Warsaw 2007.

[30] Szwaja S.: Hydrogen rich gases combustion in the IC engine, Journal of Kones, Warsaw 2009, Vol.16, No.4, 447-455.

[31] Szwaja S.: Time-frequency representation of combustion knock in an internal combustion engine, Combustion Engines/ Silniki Spalinowe, PTNSS-2009-SC-132, 306-315.

[32] Szwaja S.: Combustion Knock - Heat Release Rate Correlation of a Hydrogen Fueled IC Engine Work Cycles, 9th International Conference on Heat Engines and Environmental Protection. Proceedings. Balatonfured, Hungary, 2009.

[33] Cupiał K., Szwaja S.: Producer gas combustion in the internal combustion engine, Combustion Engines/Silniki Spalinowe, No. 2/2010, 27-32.

Arkadiusz Kociszewski, DEng. - doctor in the Faculty of Mechanical Engineering and Computer Science of Częstochowa University of Technology.

Dr inż. Arkadiusz Kociszewski - adiunkt na Wydziale Inżynierii Mechanicznej i Informatyki Politechniki Częstochowskiej.

e-mail: kocisz@imtits.pcz.czest.pl

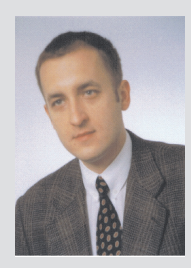

Arkadiusz Jamrozik, DEng. - doctor in the Faculty of Mechanical Engineering and Computer Science of Częstochowa University of Technology.

Dr inż. Arkadiusz Jamrozik - adiunkt na Wydziale Inżynierii Mechanicznej i Informatyki Politechniki Częstochowskiej.

e-mail: jamrozik@imtits.pcz.czest.pl

Karol Grab-Rogaliński, MEng.-post-graduated student at the Faculty of Mechanical Engineering and Computer Science of Czestochowa University of Technology.

Mgr inż. Karol Grab-Rogaliński - doktorant na Wydziale Inżynierii Mechanicznej i Informatyki Politechniki Częstochowskiej.
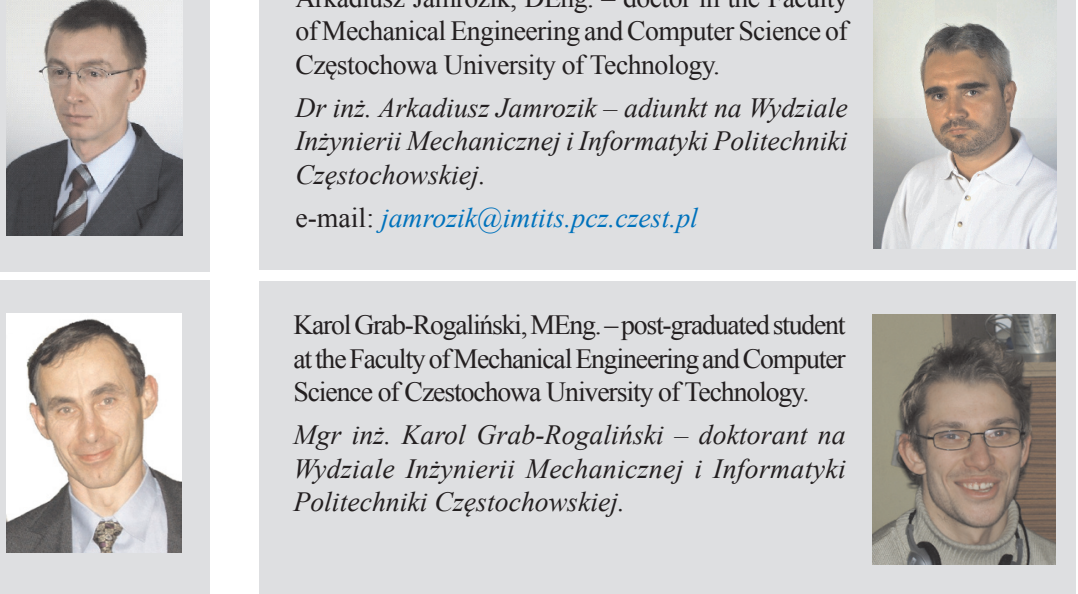